\title{
Performing the Future
}

\section{On the Use of Drama in Philosophy Courses for Science Students}

\author{
Winnie Toonders ${ }^{1}$ (D) Roald P. Verhoeff ${ }^{2} \cdot$ \\ Hub Zwart ${ }^{1}$
}

Published online: 1 October 2016

(C) The Author(s) 2016. This article is published with open access at Springerlink.com

\begin{abstract}
Drama is a relatively unexplored tool in academic science education. This paper addresses in what way the use of drama may allow science students to deepen their understanding of recent developments in the emerging and controversial field of neuroenhancement, by means of a case study approach. First, we emphasise the congruency between drama and science, notably the dramatic dimension of experimental research. Subsequently, we draw on educational literature to elaborate the potential of using drama as a teaching modality, specifically focusing on the ethical and moral dimensions of future techno-scientific innovations. Our case study consisted of a drama experiment as a module in a philosophy course on human enhancement. Twenty-two students from various science disciplines performed multiple roles, as authors, actors, audience and reviewers. Qualitative data were collected on the educational process and student performance during the course, i.e. observations and video recordings of class discussions, group work and plays, interviews and questionnaires. Our drama experiment proved to be effective in enabling students to explore and relate to a future life world affected by enhancement technologies. It allowed them to deepen their awareness of social and ethical implications of neurotechnologies and of the different viewpoints people may have on this issue in academic, professional or everyday settings. Moreover, drama allowed them to develop a reflexive position of their own in the neuro-enhancement debate by enacting a moral dilemma in front of an audience. Our results confirm the potential of drama as a tool for exploring techno-scientific futures in science education.
\end{abstract}

Hub Zwart

h.zwart@science.ru.nl

1 Institute for Science, Innovation and Society, Faculty of Science, Radboud University, Heyendaalseweg 135, 6525 AJ Nijmegen, The Netherlands

2 Freudenthal Institute for Science and Mathematics Education, Faculty of Science, Utrecht University, Utrecht, The Netherlands 


\section{Introduction}

The human brain has become the focus of attention for a plethora of large-scale research endeavours around the world (including the $€ 1.19$ billion Human Brain Project) ${ }^{1}$ and is playing a role in the global research landscape comparable to that of the human genome during the 1990s. Against the backdrop of this worldwide involvement in human brain research, the debate on neuro-enhancement (i.e. the optimisation of cognitive functioning in healthy individuals) has gained momentum as well, both in bioethical discourse and in public debate (Savulescu et al. 2011). The idea is that neuroscience may one day allow us not only to understand, but also to optimise the workings of our brain. Therefore, the societal implications of brain research have become an important topic within the 'science and society' debate, both on the academic level and in the public realm, providing relevant, up-to-date and challenging topics, both for public deliberation and for science and society and philosophy courses for students.

Our research team is involved in this debate in multiple ways. First of all, in the context of a programme of philosophy courses for science students, we developed a specialised three ECTS ${ }^{2}$ science and philosophy course entitled Enhancing the Human. Moreover, we are partners in an FP7 project entitled NERRI (Responsible Research and Innovation in Neuro-Enhancement), a 'Mutual Learning and Mobility' project devoted to organising 'mutual learning events' (such as Science Cafés and focus groups) on the societal aspects of neuro-enhancement across Europe. ${ }^{3}$ Both in our teaching and in our research, we make ample use of 'genres of the imagination' such as novels, poetry, drama and cinema (Verhoeff and Waarlo 2013; Zwart 2014a). These are seen as windows into the dynamics of contemporary science and as imaginative laboratories where future implications of current techno-scientific developments may be explored and enacted (cf. Rothenberg and Bush 2012; Zwart 2014b).

In our neuro-enhancement course, we decided to take this idea one step further by inviting students not only to read or view, but also to write and perform a play of their own. And we decided to use a Science Café event (co-organised by the NERRI project mentioned above) as a podium, allowing students to perform their play before a relatively large live audience (130 visitors). We were interested in what students would gain from such an experience. And we opted for drama because (as will be explained in more detail below) a basic affinity can be discerned between drama on the one hand and experimental research on the other. In our view, drama may function as an 'ethical laboratory', allowing students to probe and critically reflect on possible ethical and societal implications (now or in the near future) of science in general and of neuroscience in particular.

Our paper is structured as follows. First of all, we present a number of philosophical and educational views on the relationship between science and drama. This will provide a theoretical framework or scaffold for presenting and discussing our empirical work. Subsequently, we will explain how five groups of students wrote and performed a play of their own. With the help of three questionnaires, self-assessments were collected: In what way and to what extent did the students themselves see added value in the use of drama for reflection courses, as an embedded component of their science curriculum?

\footnotetext{
1 https://www.humanbrainproject.eu/.

2 The acronym ECTS refers to the European Credit Transfer and Accumulation System.

${ }^{3}$ http://www.nerri.eu/.
} 


\section{Science and Drama}

\subsection{Science and Drama: Similar or Different?}

At first glance, science and drama seem worlds apart. This notably applies to the forms of science discussed in this paper, namely brain research and neuro-enhancement research as particular forms of contemporary experimental life science research. First of all, the topology of a modern life science laboratory is structured in such a way that the outside world is systematically kept at bay. For methodological reasons, experimental life science research is preferably conducted behind closed doors, so that intrusions from the outside world are minimised. A laboratory setting involves standardised gestures, repetitive activities and daily routines, albeit often wrapped in an acoustic veil of non-stop radio music, while an audience is emphatically absent. Indeed, outsiders are basically seen as potential disturbers. Drama as an art form, on the other hand, seems impossible without an audience. Rather than routine and repetitive, the action tends to be condensed, dramatic and unpredictable. Moreover, drama typically involves surprising events and intrusive (or even aberrant) behaviours. In addition to that, even audiences play an active role, although the level of involvement of the public may be difficult to predict.

Moreover, there is a long tradition of authors who not only claim that science and drama are fundamentally different, but also believe that they should be kept at a safe distance from one another, to forgo contamination. This view was already voiced in a paradigmatic way by Plato (Boal 1974/2008; Eckert 2012), notably in his famous simile of the cave, with humans seated in rows, their legs and necks in chains, peering at a wall in front of them: a kind of stone-age cinema screen as it were. Behind them, there is a light, and between the light and the prisoners, a puppet show is being conducted, with images of humans and animals, whose shadows are cast upon the wall in front of them (Plato 1935/2000, 514A515B). According to Plato, these deplorable spectators are forced to enjoy a drama (an interminable puppet show) staged in order to narcotise, misguide and enslave them. Science is only possible, he argues, to the extent that human beings manage to escape from this claustrophobic setting, even if this means forcefully dragging them upwards towards the realm of light (which is the quintessence of a scientific 'upbringing').

Ironically, however, if we change the perspective just a little bit, Plato's cave itself becomes a theatrical stage where a drama is being conducted and a struggle for liberation unfolds: a conflict involving actors torn between captivating phantasmagorias on the one hand and the painful process of knowledge acquisition on the other. In other words, Plato (paradoxically) uses drama himself - the cave world as a highly dramatic setting, involving various theatrical elements, such as seats, a screen, a dark room and a puppet show-in order to make his (anti-dramatic) point.

Many centuries later, but clearly building on Plato, Francis Bacon likewise criticised what he referred to as the 'idols of the theatre', namely the teachings and legacies of scholastic philosophical systems, which (according to Bacon) produce phantasmagorical worlds 'in scenic fashion' (Bacon 1620/1878, Book I, Aphorism 44). But, again, paradoxically, Bacon himself uses literary, even dramatic metaphors to support his arguments.

Finally, Friedrich Nietzsche (1872/1964) argued that the death of Greek tragedy (one of the greatest theatre traditions of all time) was brought about by the principle of rational inquiry, coined and introduced by Socrates, summoning his followers to distance themselves from the drama of human existence (with its prejudices, myths and power plays) and from the tragic view of life, so as to be able to see the world in a more 'truthful' and 
rational light. And yet, in Plato's dialogues (highlights of dramatic literature in their own right), Socrates emerges as a talented actor, staging and performing his lively dialectic encounters in a variety of settings. In Aristophanes' lively portrayal of him, this dramatic element is emphasised even more notably (Aristophanes 1971).

Thus, on closer inspection, there is more affinity between science and drama than the authors discussed above seem to suggest, while the resemblances are at least as striking as the differences. Notably, a basic resemblance can be discerned between research and drama in terms of 'experimental design'. Experimentation seems an inherent part of drama as well. A play is often built around the question 'What would happen if...?' How will certain types of individuals respond when they are exposed to specific challenges and circumstances, to particular 'stimuli' as it were (such as an unexpected or even threatening dramatic event)?

Research papers and plays share a similar basic structure: starting from an initial situation (the 'control condition') in which a novelty or unexpected element is suddenly introduced (the experimental condition), which then unleashes a series of responses, building up to a certain outcome (the dramatic plot). Thus, as Crease (1993) has argued, rather than being fundamentally different from drama, laboratory research can be seen as constituting a particular kind of drama. In comparison to other forms of scholarly activity (such as making calculations or reading books), Crease argues, experimentation constitutes a highly dramatic form of inquiry, a dramatic 'art'. An experiment is basically a performance. The emphasis is on doing, on acting. And fairly often, experiments are enacted before a live audience of students, interns and colleagues. It is a performance, moreover, that involves rehearsals, repetitions and practice, while researchers may alternately function as actors, directors and reviewers. Particularly experiments involving human subjects or laboratory animals can be reminiscent of drama in the eyes of those who witness them or read about them (think, for instance, of Zimbardo's famous prison experiments, Haney et al. 1973). But basically, the theatre analogy applies to all forms of experimental research, especially in the life sciences, where the affinity between the literary drama of the playwright and the scientific drama of experimental research seems quite profound (cf. Rothenberg and Bush 2012).

This view has become quite widespread in science studies. Donna Haraway's book Primate visions (1989), for instance, can be regarded as an elaboration of the theatre metaphor in the context of twentieth-century primate research. In her book, science in general and primate research in particular are explicitly framed as 'theatre' (p. 150). 'The life sciences', Haraway argues, 'have from their birth been inherently dramatic'. In fact, nature itself is already conceived as a big theatre, a stage of immense proportions for playing out games of love and power, with primates as key actors (p. 288). Animals in the wild, she claims, 'are constantly performing an evolutionary play in an ecological theatre' (p. 535). And yet, a new and powerful dramatic element is added as soon as human researchers enter the scene.

This view, stressing the congruence rather than the difference between science and drama, builds on a long intellectual tradition. Hegel already argues, for instance, that the most important source book for understanding modern society is Antigone by Sophocles (Hegel 1821/1970; Griffith 1999). And important playwrights of the early nineteenth century, such as Goethe and Büchner, were actually life scientists who used their plays (Faust and Woyzeck, respectively) to act out some of the key dilemmas of modern scientific inquiry (Zwart 2013). Georg Büchner (1813-1837) was an academically trained physician who conducted neurological research (notably by performing cranial autopsies in fish) while writing Woyzeck: a critical dramatic assessment of the concept of congenital 
deviance (the idea of the 'born criminal', which would be further developed by Cesare Lombroso and others and which is now receiving new interest in the current era of brain research). In other words, he critically took position in an academic debate by trying out or acting out the idea of congenital deviance on stage (Büchner 1836/1980; Zwart 2013). And speaking about Faust, a famous parody of this German classic was performed at the Niels Bohr Institute in Copenhagen in April 1932, written by Max Delbrück and featuring Niels Bohr as God, Wolfgang Pauli as Mephistopheles and Paul Ehrenfest as Faust. This version, which came to be known as the Blegdamsvej Faust, visualised the struggle of modern physicists (including these four Nobel laureates) with the idea of the neutrino as a weightless particle. The neutrino was cast in the role of Gretchen singing at her spinning wheel: 'My mass is zero, my charge is the same ... Neutrino is my name' (Gamow 1966, p. 188). Apparently, the play functioned as an effort to 'domesticate' the remarkable and even disturbing new insights of quantum physics through dramatisation and acting out (Pantidos et al. 2001).

It can also be pointed out that some classical experiments were quite explicitly staged as instances of science theatre. A famous example is Louis Pasteur's public experiment at Pouilly-le-Fort in 1881, performed before a live audience (a sizable crowd of onlookers, farmers, engineers, veterinarians, physicians and scientists) and broadcasted by newspapers across the Western World. Twenty-five sheep were vaccinated by Pasteur (who acted both as the director and as the key protagonist in this drama), whereas the other twenty-five served as controls. Subsequently, all animals received a lethal dose of anthrax. The trial was a dramatic success. Two days after the final inoculation, every single control sheep was dead while all the vaccinated sheep were alive and healthy. It was an experiment and a public performance at the same time, an experimental 'show' (Debré 1994/1998, p. 397), a 'theatre of proof' (Latour 1984/1988, p. 85). Via the assembled media, who reported the events meticulously (Latour 1984/1988, p. 87), a large educated public became involved in the 'daily drama' of scientific trials. Pasteur, the 'scientific showman', the 'actor', the maker of 'theatrical gestures' (De Kruif 1925/2002, p. 234) marched into the arena 'like a matador', facing dignitaries, farmers and other visitors of all walks of life. The societal consequences of his trial (the large-scale 'pasteurisation' of animal husbandry, about to unfold throughout the Western world) would constitute a drama in its own right.

A final example of science-as-theatre is taken from The Double Helix by James Watson, featuring Nobel laureate Linus Pauling during the era of model building in molecular biology who, when presenting a protein structure during a lecture, would keep his model hidden behind a curtain, unveiling it only at the very end of his talk, leading Watson to comment that it was 'as if he had been in show business all his life' (Watson 1968/1996, p. 25). Many more instances of science theatre could be given. The congruence between science and drama is not only food for philosophers or historians of science, however, but recognised by experts in science education as well.

\subsection{Science and Drama: Pedagogical Perspectives}

The connection between science and drama has received due attention in science education as well. Fels and Meyer (1997), for instance, argue that 'drama in theatre and science share some common ground... both seek explanations of the world through real, imagined or vicarious experience' (Fels and Meyer 1997, p. 75; cf. Braund 2015). Drama and more specifically role-play offer powerful methods for engaging students in learning activities with a high degree of interaction, allowing them to actively co-construct meaning together with their teachers and peers, assuming an active role (Wilson and Spink 2005). It may 
foster the acquisition of cognitive, procedural and affective knowledge in an integrated way (Ødegaard 2001, 2003; Dorion 2009). Essentially, two approaches in drama or roleplay to enhance science learning can be discerned (Smith 2015): the more common use of drama/role-play in facilitating conceptual understanding in science and drama to explore the human impacts of science and (emergent) technologies on society, including ethical and controversial issues. The use of drama for conceptual understanding aims to make complex or abstract concepts concrete and hence clearer. Students can act out chemical reactions and structures, (micro-)biological processes such as photosynthesis or DNA replication or dynamical food webs, or how body systems or machines work (Smith 2015). While science education traditionally focuses on the transfer of methods and concepts, drama has a lot to offer notably when it comes to addressing the societal dimensions of science. It may allow students to engage in 'simulation' exercises by means of which the societal impact of science can be explored and enacted, providing a stage, a test bed for testing alternative (perhaps conflicting) perspectives, inviting students to explicitly reflect on the tensions and differences that are made visible and tangible this way (Colucci-Gray et al. 2006). Emerging technologies often involve uncertainties when it comes to their potential (medical, environmental or economic) benefits and risks, and drama seems especially apt to capture and articulate the ambivalence this entails. McSharry and Jones (2000) argue that, driven by the teacher, role-play in science education can utilise learners' lifetime 'play practice' to both express themselves in a scientific context and develop an understanding of difficult concepts. They argue that engaging learners in creation and performance of science drama provides a physical and creative experience that may be more appropriate for personal learning styles, offering them a sense of ownership of their education. They also underline its potential for effective learning about moral and ethical issues such as genetic modification in food production.

Nonetheless, although the conviction that the well-considered use of drama may offer empowering learning experiences to students seems widespread, the actual number of empirical studies on drama in science education is fairly limited (Cakici and Bayir 2012; Braund 2015). Braund illustrates this by noting that of the 700 papers presented at 'one of the world's largest international science education research conferences in 2011' [namely the conference of the European Science Education Research Association (ESERA) in Lyon, France], only 2 papers addressed the added value of drama experiences, compared to over 100 papers dealing with the learning experiences involved in 'discussion and argumentation' (Braund 2015, p. 103). So far, only a few empirical studies have been published concerning the impacts of the use of theatre in science education (Shepherd-Barr 2006; Wieringa et al. 2011; Cakici and Bayir 2012).

The research conducted by Wieringa et al. (2011) involves a play performed by professionals before an audience of high school students. They argue that, when it comes to exploring the societal implications of science and technology, imagination plays an important role. Drama may open up a future life world with which the students/spectators are invited to engage. By viewing the performance, the students are expected to imagine how they themselves would act in such a situation. The enactment of a dramatic narrative allows the student audience to witness how societal issues unfold before their eyes, and this may be an enlightening experience, for instance through identification with one of the characters. But it may also incite them to explore alternative solutions to the problems raised: a crucial element of critical pedagogy.

Contrary to such staged theatre productions in front of a (student) audience, 'drama in education' explores the use of less formal forms of drama to support collaborative learning in the classroom. It often involves students in improvised role-plays within a fictional 
context (Bolton 1984, 1985; Heathcote and Bolton 1995; Neelands 1984). In these dramatic settings, the distinction between actor and audience has faded; the learner is both participant and observer, playing a role while interacting with peers (Andersen 2004). It is concerned with exploring ideas and feelings and taking different perspectives. In the process of participating in the drama, and during reflection and evaluation, the participants 'live through' the drama rather than watching it from the outside (O'Neill 1995). In their roles, both teacher and students are actively reframing and adapting their perceptions of the world and the people within it. Reflection and analysis of the drama helps to extend and deepen understanding of what might be termed as 'the human condition' (McNaughton 2004, p. 142).

Bolton argues, moreover, that the effect of drama is created by the interplay between the real and the fictitious world, which are necessary to be held in mind simultaneously (Bolton 1984). Imagination in classroom drama enables learners to engage in an 'As if...behaviour' by which they can examine problems and find solutions. Drama requires them to envision possibilities and alternatives. The experience of inhabiting both the real and the imagined world, and being aware of both, allows learning to take place by deepening the level of cognitive involvement (Heathcote 1978; Bolton 1985). Without an 'external' audience in drama education and the necessity to make dramatic representations plausible by means of a plot, script and setting, the teacher should create the conditions under which the purposes of the drama and expectations are made clear. The success of learning via drama depends to a considerable extent on the degree to which participants create links between the world of fiction and the real world (O'Neill 1985). Using drama as a tool to learn science, Braund (2015) has described the key ability of teachers as allowing space for student reflection on the extent to which their acted roles, movements or talk are realistic presentations of the science represented (Braund 2015, p. 115). This requires teachers to cross pedagogical borders from the pedagogy of drama to the pedagogy of science and vice versa (Fels and Mayer 1997; Braund 2015). This is not self-evident for most science teachers, as they may perceive a loss of control when their students are improvising in an experiential setting. For teachers and learners more used to traditional educational activities or rational science teaching, e.g. university (science) students, McSharry and Jones (2000) suggest the use of structured games, simulations such as organised debates or court cases or plays scripted by the teacher or students in advance.

Sceptics such as Redington (1983), however, argue that the impacts of using drama in science education are difficult to measure, in view of the complexity of the learning situation involved. Cakici and Bayir (2012) underline this complexity and argue (in line with research practitioners mentioned earlier such as Heathcote and Bolton 1995) that the positive effect of activity-oriented learning activities such as drama is stronger when they include opportunities for students to discuss and reflect on what they have learned. Although the effect of drama cannot be studied in isolation, interviews with students and teachers and observations of classroom activities may shed light on how drama improves engagement and learning of students.

Building on these philosophical and educational sources and debates, we decided to set up a theatrical module for science students ourselves, inviting them to explore future societal impacts of emerging neuro-technologies with the help of drama, written and performed by the students themselves. This module was part of a philosophy course conducted by colleagues working at our department, which provided a basis for writing the script. As indicated, our initiative was part of a European FP7 project designed to stimulate mutual learning processes between various stakeholders (producers, users, academic experts, industry, patient groups, intermediaries, etc.) concerning emerging technologies in 
the area of neuro-enhancement. Therefore, one of the plays produced by the students was selected to be performed before a Science Café audience in order to stimulate the debate.

\subsection{Research Questions}

We started with a number of preliminary questions. For instance: Will drama merely 'illustrate' the issues involved (Livingston 2006, p. 11), or will it rather provide a stage where scenarios and concerns can be actively explored and tested, so that drama becomes a kind of ethical laboratory? In many papers describing the use of drama in science education (such as Wieringa et al. 2011), students are typically involved as spectators. They are exposed to drama, but usually they do not actively perform themselves. In our case, we followed the tradition of research practitioners in 'drama in education' such as Heathcote, Bolton, O'Neill and others by involving students not only as an audience, but also as authors and actors. In contrast to Heathcote and others, however, our drama approach was not based on improvisation. Following the suggestion by McSharry and Jones, we decided that the performance should be based on a script, but in our case this script was written by the students themselves. The teachers' role was to safeguard the realness of the play (i.e. the links between their imagined world and reality, cf. O'Neill 1985).

Our research question was: What would be the added value of this multifaceted, active involvement of students (as authors, actors and audience)? Would it deepen their understanding of the philosophical and societal dimensions of the scientific developments addressed? We expected that, like a laboratory experiment, drama would allow students to probe and enact possible actions and decisions in a relatively safe (intrusion-free) environment (cf. Bolton 1984). Possible 'what if... scenarios' could be staged and tested in an experimental fashion, building on the basic affinity between drama and science: the dramatic experimental design. What will the introduction of a certain intervention or technological novelty entail?

\section{Method}

\subsection{The Drama Activity}

Over the last two decades or so, neuroscience has developed new technologies to influence neural processes. Most of the treatments and technologies involved are developed for therapeutic purposes, but may in principle also be applied to healthy individuals to optimise cognitive performance (notably in the case of so-called challenged professions, such as pilots, top athletes or the military). Thus, human enhancement has become a key topic for ethical deliberation (Savulescu et al. 2011). Enhancement technologies include genetic engineering, nootropic drugs (e.g. modafinil), brain-computer interaction (BCI), neural feedback, non-invasive brain stimulation, neural implants and so on. According to both advocates and opponents, these technologies may significantly boost human performance in the near future and already raise various ethical quandaries concerning autonomy (Will we as individuals be 'empowered' by them, or will we rather be forced to use them in an era of increased cognitive competitiveness?) and justice (Will these technologies boost social mobility or rather increase the socio-economic divide between those who will and those who will not have access to these opportunities?). On a more fundamental level, it raises the question whether and how it will affect human nature, human identity and human 
agency. We decided that these issues are optimally suited for a theatrical educational experiment.

As indicated, the dramatic module was part of a philosophy course of three ECTS $(80 \mathrm{~h})$. This course, designed for science students, was entitled Upgrading the human and was devoted to philosophical and societal issues in human enhancement, notably neuro- or cognitive enhancement. Twenty-two master students from various scientific fields (biology, neuroscience, informatics, biomedicine, philosophy) were enrolled in this course and participated in our drama experiment. The course was taught by two academic teachers with backgrounds in philosophy and biology. One of the authors (W. Toonders), with a background in biology and science communication, acted as a teaching assistant and explained the set-up of the module. After a series of introductory lectures, readings and group assignments, we invited the students to become both the authors and the performing actors of a short play ( $8 \mathrm{~min}$ ) that would be presented to the other students of the course. Traditionally, science theatre places students in the more passive position of audience, as we have seen. In that case, others have already written the play and professionals or trained amateurs are brought into perform it. In our case, student teams were invited to perform all these theatrical roles: (a) designing and writing a play, (b) performing it before an audience of peers and (c) watching and assessing the performances of others. We expected that by allowing them to play a more active role, the processes of imagination, exploration and identification would become even more intense. The play would enable students to 'try out' their envisioned scenarios in a relatively 'safe' environment, before the new technology enters the real world.

In other words, our dramatic activity combined the two dimensions of drama as described by Schaffner et al. (1984), namely the 'experiential' and the 'presentational' one. While the 'presentational' dimension involves students as audience (asking them to reflect on, or even to take sides in, the conflicts that are acted out on stage), the experiential dimension allows them to become authors and performers as well, thus exposing them to dialogic experiences that may encourage them to actively adopt a particular view or attitude vis-à-vis the issues at hand. Five short dramas were written and performed by five groups of students..

A final element was added when we invited the 'winning team' (i.e. students who, according to their peers, had written and performed the best play) to perform their drama in a Science Café, during a discussion evening devoted to the human enhancement issue (organised in the context of the NERRI project mentioned above). Thus, the play was taken out of its original educational context (the university building) and brought before a large audience of 130 spectators. This required the authors/actors to actively reconsider the message they wanted to convey and the type of dilemmas they wanted to address.

Thus, the drama experiment focused on two main learning objectives:

- Enable students to position themselves with respect to important issues in the ethical, political and philosophical debate on human enhancement

- Enable students to apply the conceptual arsenal offered by their course to a concrete case of human enhancement with the help of drama

While students in their role as authors and actors actively used their imagination, as audience they represented the 'reality principle', i.e. assessing and discussing the plausibility and credibility of the enacted scenes (cf. O'Neill 1985) Thus, an intense dialogue unfolded among students playing alternating roles. 


\subsection{Structure of the Module}

The module included four collaborative student activities, namely: 1) writing the script, 2) performing the play in a classroom setting, 3) observing the other plays in the same setting and finally 4) either performing the play at the Science Café (the 'winning' team) or observing the performance and the interaction between performing students and the Science Café audience. The students were prepared and inspired for their module by the other components of the course (lectures, group discussions). We first present the design of the module in more detail. Then, the methods for data collection and data analysis are described.

After explaining the purpose and design of the module in outline, we first asked the students to write a short statement about their background, their experience with drama and their expectations of the course, including the module (questionnaire 1). Subsequently, the twenty-two students were allocated to five groups, consisting of four or five students each. These groups were asked to write an eight-minute play and to perform their play in class before their fellow students and teachers. Finally, we asked the students to assess the quality of the plays performed by their peers (questionnaire 2).

To make the comparison of their performances more feasible, we asked students to focus on a particular neuro-enhancer, i.e. a medication or a technical device expected to enhance cognitive performance (such as a pill, a chip, a computer program, an implant and robotics). Students were requested to stage a plausible setting sometime in the near future. With respect to the content, students were asked to develop a dramatic storyline that would provide insight into the various options and dilemmas that the characters face, making choices connected to a particular (experimental or hypothetical) neuro-enhancer, employable in a particular context. In other words, they were expected to clarify the Who, the What, the How, the Where and the When on stage.

In our instructions we explained that the dramatic storyline should consist of at least three scenic elements: (1) an initial situation, (2) an occurring event and (3) an ending. In addition, students were asked to think about the presentational aspects of their play, e.g. using expressions to show emotions and allowing the audience to form an opinion. All this resulted in five short plays. For 'presentational' considerations, students were encouraged to write and perform the play in such a way that the spectators would be encouraged to form a view of their own, for example by using an open ending plot device. Moreover, students were asked to write out the whole screenplay (characters, words, events) beforehand, rather than relying on improvisations, including short descriptions of the main characters and the words spoken by them, as well as non-verbal expressions of emotions.

The process of developing the play, during class and small group meetings where the students worked on the plays in small groups, was supervised by the teaching assistant. These sessions were recorded on audio and video. During these moments, we interfered as little as possible, but reminded them from time to time of the requirements of the assignment. All students were invited to attend the Science Café, but only the 'winning' group of students was asked to perform. Finally, all students were invited to reflect (by means of an assessment form) on the choices they had made, the quality of the learning experience and the added value of a live performance (questionnaire 3 ). 


\subsection{Data Collection}

Qualitative and quantitative methods were used to collect and analyse data from students and teachers who participated in the course and attended the dramatic activities (both during the course and at the Science Café)

As explained above, to assess students' experiences and perceived learning, we developed and distributed three questionnaires to all participants before, during and after the course. The first questionnaire mainly focused on students' awareness of socio-scientific issues and prior knowledge of neuro-enhancement. The second questionnaire asked students to reflect on the plays that had been performed. The final (and most elaborate) questionnaire included questions about their self-perceived learning, their attitude towards the issues and their appreciation of the different course elements, but focusing on the design and performance of their play. For the questionnaires, we used open questions and five-point Likert scales, ranging from 1 (no, absolutely not/I strongly disagree), 2 (no/I disagree), 3 (neutral/I am neutral), 4 (yes/I agree) up to 5 (yes, a lot/I strongly agree) (see Appendix 1, 2 and 3).

In addition, the academic teachers were interviewed through semi-structured interviews after each session to reflect on the teaching-learning process. With regard to students' performance, the teacher was asked to comment on attitudes, skills and insights acquired by the students. Finally, the teacher was asked to reflect on the impact of the plays on the audience: both on the peer group during the course and on the lay public at the Science Café afterwards.

\subsection{Data Analysis}

Our data analysis builds on the analytical framework developed by Dorion (2009) and includes information on students' background, activity, aspects of learning and practical features (Table 1). Initial findings (student evaluations) were cross-checked with teachers' experiences via interviews. In addition, all class discussions and performances were videotaped, while audio recordings were made of the group discussions related to the assignments. Before presenting the results, we will first of all present the five plays in outline.

\section{Developing the Screenplay}

As mentioned above, each group of students was instructed to design an 8-min play and to write out the whole screenplay,

The boxes below present short summaries of the five plays, supplemented with quotes taken from the third questionnaire ('message'):

Table 1 Framework for case analysis

\begin{tabular}{lll}
\hline Themes of analysis & Relating to \\
\hline $\begin{array}{l}\text { Background/prior } \\
\text { experience }\end{array}$ & $\begin{array}{c}\text { Students: prior knowledge and drama experience, motivation for enrolling in } \\
\text { this course } \\
\text { Teachers: teaching objectives; perceptions of learning and teaching science in } \\
\text { relation to drama }\end{array}$ \\
2 Activity & $\begin{array}{l}\text { Observation of plenary and group activities and performances } \\
\text { Aspects of Learning }\end{array}$ & $\begin{array}{l}\text { Students' self-perceived learning during and after the drama activities } \\
\text { Teachers' and researchers' evaluation of student learning }\end{array}$ \\
4 & Practical features & Issues of classroom management, classroom layout and time management \\
\hline
\end{tabular}




\subsection{Group 1: Memory chip doctor}

Two candidates have a job interview for the same job, that of senior surgeon. The first applicant is a young but arrogant surgeon who recently finished his medical training with the help of an implanted memory chip giving him a photographic memory. He looks down on non-enhanced medical professionals. The second applicant is an experienced and skilled surgeon without a memory chip, but with a social personality. Both applicants have a similar interview. The young doctor is able to answer each question quickly and accurately, while the older doctor is clearly under pressure of keeping up with the new generation of 'enhanced' doctors.

In the next scene, the enhanced doctor is barging in a bar, exclaiming to his friend that he got the job. Not so coincidentally, the older doctor is there as well and is angry that the younger enhanced doctors steal the jobs. He argues that these doctors lack creativity and are only accepted because of the knowledge on their chip. The younger doctor responds that this amount of knowledge leads to optimal decisionmaking on behalf of patients. He states that every doctor should have a chip implanted, as a professional obligation.

Message: 'We juxtaposed empathy, experience, and creativity with rational decision making, flawless memory and procedural strictness in order to provoke discussion as best as possible. Memory enhancement will have a large impact on our society, specifically in the way we treat each other as social, working, and responsible beings.'

\subsection{Group 2: Future family}

God looks down from a cloud into the world and sees that humans are changing. They are improving themselves with neuro-enhancers, i.e. smart pills that increase their thinking abilities, creativity and drive to be the best. God 'shows' the audience two families both consisting of a mother, a father and two children. One family take enhancement pills daily, while the other family lives without neuro-enhancers. In the non-enhanced family, two sisters are doing their homework. The youngest is helped by the oldest and gets support by the argument that a person does not need to be the best in everything and that everyone has their own talents. She, for example, is good in painting. Her confidence grows by the compliment. In the enhanced family, the mother gives all family members a smart pill in the morning and hurries to her work. The children are very competitive and both hurry to finish their homework and paintings, which are both equally good. With the help of the smart pill, they are excellent in everything, which is important for their dad, who says that Achieving as many goals as possible is the ultimate human being.

Message: 'With this play we wanted to present an idea of how the world would look like with neuro-enhancement, and what the consequences could be. We wanted to show that the quality of life is very important, but there are multiple ways to interpret this term. Someone can value the qualities that a human has from birth, but others focus on the results (with or without neuro-enhancement). There is no good or bad, it is a different way of living a life. Neuro-enhancement is one of those subjects that can cause this separation. The people that value the individual and respect that are most likely are not pro-neuro-enhancement. But if you are very competitive, than it is a promising topic and worthy to explore it even further.' 


\subsection{Group 3: Robot bartender and friends}

Three unemployed friends are talking in a bar. One of them just lost his job as a head of the psychiatry department where he was replaced by a robot. He questions whether robots can understand human behaviour and emotion better than humans themselves can. Despite their knowledge and speed, they have no emotion and empathy. The second friend lost his job as a bartender to a robot as well. The third friend states that we humans have invented these machines ourselves, initially to resolve the climate problems, and points out that the friends had the choice to enhance themselves but they opted out. A fourth friend enters and enthusiastically tells them he just sold a painting and explains that creativity is a human characteristic that robots will never have.

When the friends order another beer, the robot bartender points out that, according to his estimates, they have crossed their alcohol limit and he asks the friends to leave. When the friends have left, the robot starts a sad monologue. People never thank him and his fellow robots for the things they do for them. He describes their history and that people chose to stay true to their nature instead of enhancing themselves. He explains their shared history and mutual dependence. People owe everything to robots and the robots owe everything to them.

Message: 'The robot is telling the message and symbolizes technological advancement. Fear of increasing technological influence in our lives is not a fear that should necessarily be cast at the technology itself, but rather at society with co-evolves with technology. The point that we will be trying to make as convincingly as we can is that the fear of increasing technological influence in our lives is not a fear that should necessarily be cast at the technology itself, but rather the society with which the technology co-evolves.'

\subsection{Group 4: Talk show about memory alteration}

A talk show host asks the public what they would do if they had the power to erase mistakes or redesign their lives. Then she introduces the topic of today: 'Wish fulfilment or wishful thinking'. 'Better Life Agency' produces a technology that changes memories by replacing bad memories and implanting new dreams. Two guests, a client and Mister Watson from the agency, present some arguments in favour of the technology. A third guest, who is a doctor and writer, criticises it. The client describes the technology as a chance to fulfil dreams you never had the time for. In her memory, she has a life behind her as successful business woman. Mister Watson explains that there have never been complications or bad side effects and they are successful in reaching their aim to make people mentally healthy. However, she cannot guarantee that it is entirely safe.

The doctor questions the definition of 'perfection' and explains that society is imposing its view on us. She also questions the reality of the new memory and points out that mind alteration could have negative side effects. 'Are you aware that your memories are not true? That can cause a conflict in yourself, and lead to disorders and self-destruction by escaping from your own responsibilities in life. Does it really make you happy? Or does acceptance make you happier?'

Message: 'We try to show both sides of the discussion: the attractive aspects of the technology as well as main concerns for the future (safety, the concept of perfection, reality and being in conflict with oneself).' 


\subsection{Group 5: Parents discussing about their child}

A mother asks her 10-year-old son whether he would like to play something on the piano. The child refuses because he says it is boring. The mother insists and asks him what his problem is. The boy used to love playing piano and that suddenly seems to have disappeared. The child finally agrees and starts playing. It turns out he is extremely good. The mother gets suspicious, and when the father, her exhusband, enters, she accuses him for giving their son smart pills. They end up in a discussion, where the father pleas in favour of neuro-enhancers and strongly opposes. In the end, the father agrees to stop giving their child smart pills. He leaves the house with their son, but leaves the pills on the table. The mother overthinks the arguments of her ex-husband and decides to take a pill herself.

Message: 'We show a daily life scene that could occur in the future with regular people with opposing views to show the different arguments in favor and against the use of smart pills. (...) We want the audience to think about enhancement, before they actually will start using enhancement pills themselves (...) because we think that neuro-enhancement could change the way we interact with each other.'

\section{Results}

\subsection{Performer line up: backgrounds and inspiration}

The 22 students attending the course formed a pluralistic community in terms of disciplinary backgrounds and nationalities, but they were fairly homogeneous in terms of age (between 21 and 29 years, with an average age of 24). The majority of students had a bachelor's degree in the life sciences: medical biology (9 students); chemistry (5); molecular life sciences (1); and biology (4), while others had backgrounds in physics (1); artificial intelligence (1); and philosophy (1). This broadness of expertise proved an asset to the course. Most students (15) were Dutch, but seven of them came from abroad: Germany (5), Italy (1) and Brazil (1). Five students considered themselves religious. Most students indicated that they took this course because they were interested in human enhancement and wanted to gain more insight into the ethical issues concerning this future technology. Only two students had prior experience with performing a play before an audience. As a consequence, the prospect of a live performance initially raised some concerns among the students.

In the first questionnaire, seven students indicated that they expected that this module would help them to express their views and opinions in a creative manner and in a different way than they had done so far. Other students expected that this would allow for more creativity in developing their views (2) or that they looked forward to hearing the views of other students (3). Some students indicated that they were not sure what to expect from our module (3).

During group discussions, concrete examples of neuro-enhancement presented by the students, were discussed, such as the idea of a 'memory chip'. Would it lead to inequality (by creating a neurologically enhanced elite)? What would be the impact on human nature if important capacities such as memory no longer needed to be trained and challenged? Would it be good or desirable to remember everything? In other words: Does not forgetfulness serve a purpose? Also, issues of autonomy were addressed: Would it be 
objectionable to implant memory chips in children? Who is to decide? Also, comparisons with other (already available) types of implants were made (such as cochlear implants).

In questionnaire 3, we asked students what course elements helped them in designing the play. The results (see Table 2) show that elements where students had to work and discuss in groups were regarded as most fruitful. Observation of the group and whole class discussions showed that students were able to formulate their own initial opinions, questions in reaction to each otheŕs statements and collaboratively discuss relevant societal issues related to the neuro-enhancer of their choice.

\subsection{Activity: Neuro-Enhancement Dilemmas in Context}

When it came to designing the plays, all students focused on presenting concrete applications in particular settings. Moreover, in all the plays, very contrasting views were presented. In other words, building on the experimental metaphor already introduced above, all teams decided to enact both an enhanced and a 'control' condition. This was done in various ways, for instance by staging an enhanced versus a traditional (nonenhanced) professional (a physician with or without a memory chip implant, Group 1); or by comparing an enhanced with a non-enhanced family, sometime in the future (Group 2); or by presenting the story of a traditional worker, out-competed by a robot (Group 3); or by staging a discussion between experts who supported and experts who criticised a new technology (Group 4); or, finally, by presenting a discussion between the mother and the father of a juvenile candidate for enhancement therapy (Group 5). As one of the participants phrased it: presenting multiple viewpoints on stage 'allowed us to shed more light on the topic from different angles'. Whereas four groups decided to present various viewpoints in a more or less 'neutral' fashion, leaving it to the audience to decide, one group (Group 1) explicitly presented the non-enhanced professional as more social, friendly and committed than his enhanced rival, who was depicted as arrogant and insensitive.

Furthermore, various contexts were chosen as a backdrop for enacting future implications of emerging enhancement technologies, varying from professional settings up to private and educational environments. For instance, two groups ( 1 and 3 ) demonstrated how untreated humans may be outcompeted by robots or enhanced humans at work. Other

Table 2 Responses of students $(n=17)$ on the statement 'Did the following course elements help you in designing the play?' on a Likert scale ranging from 1 (no, absolutely not), 2 (no), 3 (neutral), 4 (yes) up to 5 (yes, a lot)

\begin{tabular}{|c|c|c|}
\hline \multirow[t]{2}{*}{ Did the following course elements help you in designing the play? } & \multicolumn{2}{|l|}{$n=17$} \\
\hline & $\begin{array}{l}\text { Mean } \\
\text { score }^{\mathrm{a}}\end{array}$ & $\begin{array}{l}\text { Score } \geq 4^{\mathrm{b}} \\
(\%)\end{array}$ \\
\hline Presentation of a short statement regarding neuro-enhancement: & 3.69 & 69 \\
\hline Whole class discussion on SSI's related to neuro-enhancement: & 3.82 & 76 \\
\hline Group discussions on the Sessions with your own group: & 4.24 & 88 \\
\hline Information given in lectures: & 3.65 & 71 \\
\hline $\begin{array}{l}\text { Examples of movies/theatre plays/books addressing ethical issues of neuro- } \\
\text { enhancement }\end{array}$ & 3.35 & 47 \\
\hline
\end{tabular}


students showed how enhancement could make life easier for humans (Groups 2 and 5), by making people more creative, but less social (Group 2), or more effective in performing their professional tasks (Groups 1, 2, 3 and 5), although the question was also raised whether enhanced professionals could really be trusted in complex situations (Group 1), and whether unforeseen collateral damage might be involved (Group 4). These proved to be questions for which a 'dramatic experimental' laboratory seems suitable.

In our third questionnaire, we invited the participants to reflect on the question why they had chosen a particular setting or story. One of the groups (Group 4) initially found it difficult to reach consensus about a common storyline, mainly because their views on what context to choose for the scenario diverged quite noticeably, e.g. realistic versus nonrealistic, and a scientific context versus a personal (everyday) situation. In the end, they decided to stage a television debate, but in such a way that the characters were expected to present the views that the students themselves actually rejected: 'Our characters showed all the problems and possibilities we could imagine'.

All groups tended to use recognisable human characters, thus giving their viewpoints a human voice and face. Group 5, for example, 'chose a family, because it is an important and recognizable scene for the audience' and because enhancement is expected to influence the daily lives of ordinary people 'we thought that a comparable situation could occur in the future'. The same goes for Group 2: 'The family is the smallest 'group' in terms of social interaction, so changes will be quite noticeable there'. As is shown by these quotes, students intended to design a realistic futuristic setting. Another reason for choosing a family mentioned by Group 5 was that they took the presentational conditions of the play into consideration as well. Group 1 came up with a dramatic device that proved very effective from a theatrical point of view, meant to provoke discussion: 'We were thinking about influences in social and work settings. Step by step we created the play ... We thought memory chips would be a perfect example of a futuristic neuroenhancer ... It was a good way to juxtapose two different positions on enhancement'. In their play, both scenes were visible on the podium, but while one of them was being performed, the other one would be temporarily frozen, and vice versa. This strengthened the element of contrast: the awareness that there are two options. Also, students in general agreed that short and powerful statements or comments worked much better than extended monologues. Humour and commitment demonstrated by student actors were appreciated as well and regarded as success factors.

During the rehearsals, students noticed that it is important to present the viewpoints in a plausible, quasi-spontaneous and realistic manner. They discovered that stereotypical exaggerations and the absence of any signs of ambivalence and doubt could easily become counterproductive. One of the groups (Group 5) decided to make two lists of arguments (one with arguments in favour, and the other with arguments against enhancement) and to divide these among the key characters (the father and the mother). Two groups reported that they tried to 'personalise' the arguments by placing themselves in the characters' positions, after having thoroughly discussed the topic, the issues and the message to be implemented in their play. Subsequently, they started to improvise to see what worked (Groups 3 and 5). One of the lessons learned during these rounds of improvisation was that it is important to get the details right. In the case of Group 5, for instance, this involved questions such as: 'How old is the child? What is the relationship between the parents? What are the uncertainties concerning the effectiveness of the pill?' Students became aware that all this information should be built into the script. Also, students noticed that their message became clearer and convincing when they arranged a logical and coherent sequence of events. Finally, given the possibility of a live performance in the Science Café, students proactively tried to take possible responses of the public into account. They noticed that a debate between conflicting views would encourage spectators to take sides, notably when the issues were 'serious enough', and that 'it is much easier for people to relate to 
plausible developments than to futuristic stuff'. The staging of contrasting views tended to work quite well because 'it forces you to think about perfection', as some of the students phrased it.

\subsection{Learning Outcomes: Self-Reported Learning}

After the course, students were invited to fill in the third questionnaire. The results are presented in Table 3.

According to the results of the final questionnaire, presented in Table 3, the majority of students indicated that our module helped them to gain insight into complex ethical issues related to neuro-enhancement and improved their understanding of other people's opinions and arguments. Moreover, it helped them to develop their own opinions about the dilemmas at hand, although they experienced difficulties in substantiating their own opinion. One of the participants indicated that he notably appreciated the peer-to-peer learning aspect of the play. It gave him 'the opportunity to hear different opinions on the issue, because mostly one is presented with expert-opinions and not so much with those of people who have the same level of knowledge'. This could also explain why students tended to disagree with the statement that the theatre assignment taught them 'how to communicate their message to experts'. Rather, they felt they had learned how to address a lay audience. It was appreciated that the use of drama encouraged active involvement: 'it was essential to really think about the topic, because this was necessary to deliver a message to others'; and: 'the play asks a lot of creativity to show a complex ethical issue in a simple way so the message will be clear to the audience'.

Another positive aspect of the module mentioned by the students was that it broadened their perspective. One student argued that drama is helpful for science students because researchers 'will sometimes have to justify themselves and their work to other people', and

Table 3 Responses of students $(n=17)$ on the statement 'The theatre assignment helped me to gain insight into...' on a Likert scale ranging from 1 (totally disagree) up to 5 (totally agree)

\begin{tabular}{|c|c|c|}
\hline Contextualisation (explore future scenarios) & $\begin{array}{l}\text { Mean } \\
\text { score }^{a}\end{array}$ & $\begin{array}{l}\text { Score } \geq 4^{b} \\
(\%)\end{array}$ \\
\hline How emerging technologies could influence daily life & 4.24 & 94 \\
\hline Future scenarios of emerging technologies & 4.18 & 88 \\
\hline Personal dilemmas in daily life related to neuro-enhancement & 4.35 & 94 \\
\hline Social controversies that might arise & 4.18 & 82 \\
\hline Complex ethical issues related to neuro-enhancement & 3.82 & 71 \\
\hline Translate complex issues to concrete daily life situations & 3.88 & 88 \\
\hline \multicolumn{3}{|l|}{ Explore viewpoints } \\
\hline Other people's opinions and arguments & 4.24 & 88 \\
\hline Other people's interests & 3.53 & 53 \\
\hline Working in groups & 3.53 & 59 \\
\hline My own opinion about the dilemmas related to emerging neuro-technologies & 3.94 & 71 \\
\hline Formulate and substantiate my opinion & 3.29 & 47 \\
\hline \multicolumn{3}{|l|}{ Communicate to public } \\
\hline How to communicate my message to a lay audience & 3.59 & 53 \\
\hline How to communicate my message to experts & 2.82 & 18 \\
\hline
\end{tabular}

\footnotetext{
${ }^{\text {a }}$ The mean score was calculated as the sum of all student responses on a five-point Likert scale from 1 to 5 $(1=$ no, absolutely not, $5=$ yes, a lot $)$, divided by the number of responses

b Percentage of student responses on a five-point Likert scale with a score equal or higher than 4 ( $4=$ 'yes', $5=$ 'yes a lot')
} 
this may involve elements of role-playing. Most students said they would recommend the course to other students. In general, teamwork was evaluated positively, with exception of one group in which collaboration had been a challenge.

Also, communicative or presentational aspects were valued by students: 'It was good to practice in presentation, though I am still very bad at it'; 'The play forces you to translate expert knowledge to a lay audience: that is something I want to learn to do better'.

At the same time, a number of drawbacks were mentioned as well. Although the majority of students were positive about the play, three of them evaluated the module in negative terms. One of them remarked: 'I don't think performing drama contributes a lot to philosophy and I don't like to perform in public'. Also, a number of students regarded the drama module as rather time-consuming, compared to other elements of the course. Finally, we decided not to give marks for the play and the performance, and this disappointed some of the participants.

As already mentioned, one group of students was asked to perform their play at the Science Café. This gave them extra opportunity to improve their work. They performed before a relatively large audience (130 people, in a crowded Science Café establishment). To better prepare, these students were supported by a colleague at our department who is a part-time philosophy professor with a background in theatre (who was both a director and an actor). During this session, attention was given to acting skills, the use of voice and position on stage, so as to ensure that they would be audible and visible for the audience. They were, for instance, advised to speak louder, to emphasise/highlight important lines and to overact their expressions, so as to guarantee that non-verbal communication would come across. As a result, the students gained more confidence after the training and visibly enjoyed performing for a larger audience. They regarded their performance as a success: 'That we succeeded in stimulating thoughts on this issue was proven by the fact that a lot of the topics in the discussion following the play were directly linked to the issues we touched upon in our act, culminating in a debate with the audience on whether people would rather be treated by the rational and enhanced or by an empathic but non-enhanced doctor. A vote split the audience roughly in half'.

This observation was in accordance with the experience of the teachers and our own observations. The play added liveliness to the debate. During the discussion among the members of the audience, the play functioned as a resource of examples for participants. While the debate centred on the dilemma that was actually presented by the play (the 'content'), the student discussions (during their subsequent meeting in class) rather focused on the quality of the performance and on how to improve it (the 'form'). Somewhat to our surprise, after seeing the play, a relatively large number of participants (about half of the audience) would prefer to be treated by an enhanced physician, arguing for instance that, in the case of a serious illness, knowledge is more important than empathy. Thus, the play performed before a real live audience had a significant added value: it made the options and dilemmas tangible and fuelled the debate.

\section{Conclusion}

In this paper, we emphasised the congruence between science and drama. Drama functioned as a laboratory in which the various techniques for staging and expressing emotions and ideas are equivalent elements compared to the scientific components (Kottler 1994, p. 273). Notwithstanding the relatively large body of scholarly literature on this topic (as presented in the first sections of this article), drama in science education remains relatively unexplored and underused, due to a lack of understanding of what drama is and how it can be put to use in 
science education (McSharry and Jones 2000; Braund 2015). With our case study, using drama as an educational tool for teaching philosophy to science students, we hope to inspire others (notably teachers) in their efforts to boost ethical and philosophical reflections on science among students with the help of dramatisation. Our drama was a scripted moral/ ethical role-play on science in society. Devising and performing the script constituted a collaborative student-centred process, during which the teacher stimulated students' reflection to the extent to which their imagined worlds were realistic representations of the relevant science represented and depending on whether it would encourage audience deliberation.

The students in our study were already acquainted with laboratories as a research context, and were encouraged to 'export' the experimental design to a real-life situation. Thus, they were invited to probe and enact possible scenarios in a relatively safe environment, but also to increase the 'theatrical impact' of their presentation by staging a plausible dilemma that would prove sufficiently engaging to the audience. While our students were used to the rational academic context of a science faculty in which experiments and investigations are based on evidence, while planned observation and logical thinking are emphasised, the question was whether and how this type of active involvement contributes to learning with regard to the philosophical and societal dimensions of the scientific developments addressed. Or as Yoon (2006) puts it: Can science drama be incorporated in rational science teaching?

In answering the question, Yoon mentions two characteristics of science drama to take into account: the 'story' and the 'liveliness' of a performance. In our case study, the collaborative development of a script proved vital for students to 'imagine' an event and characters in a 'story' and enabled individuals' emphatic participation in the play. While situating the controversy somewhere in the near future, all student groups selected everyday-life settings they could easily relate to, i.e. a family situation, a bar conversation or talk show. This made it easier for them to explore different aspects and to develop their own personal perspective. The scripting phase also allowed the teacher to fulfil the key role suggested by a number of research practitioners (Bolton 1985; O'Neill 1995; Fels 2004) to stimulate reflection, to the extent to which their characters and story were realistic representations of the respective socio-scientific issue. In this phase, the teacher was relegated to a supportive rather than leading role in a natural way.

Although students engaged in lively discussions in their scripts, the liveliness of the performances really allowed students to talk, express and adapt their ideas in a relatively non-authoritative learning environment. Our experiences concur with the views of Bailey and Watson (1998) and Ødegaard (2004) that the experiential character of drama stimulates students to actively adopt an attitude towards, and involvement in, the science-society issue at hand, which is more demanding and engaging than merely assessing a situation from an outsider's perspective. As indicated in Table 3, students agreed that their drama experience would help them cope with personal dilemmas arising in daily life (sometime in the near future), rather than in analysing complex ethical issues on a more abstract level.

Research practitioners have stressed that the focus of drama in education is more on the process than on the product. Learners are engaged in an authentic context and learn from the choices and decisions made during improvisation, while achieving greater cognitive gains than in traditional classrooms (Andersen 2004). This is, for example, achieved by learners taking on the 'mantle of the expert' (Bolton 1985; Heathcote and Herbert 1985) in order to engage in an experiential inquiry. In our approach, students were deliberately asked to take the presentational aspect into account and as a result the 'play rehearsals' and classroom deliberation primarily focused on the plausibility and credibility of the enacted scenes (cf. O’Neill 1985) and the science-society dilemma they presented. Obviously, this 
focus on the drama product was strengthened insofar as students anticipated the performance to be enacted before a live audience in a Science Café.

Although the focus on the product of drama can be a potential problem in conceptual science learning, we did not consider it to be a problem in learning about socio-scientific issues. We rather see the three-step module, i.e. collaborative writing of a script, performing and witnessing a play in the classroom and the possibility of performing before a live audience to promote deliberation as a natural way of pedagogical border crossing (cf. Fels and Meyer 1997). Both the teacher and the science students moved from a pedagogy of science, i.e. learning about neuro-enhancement to the pedagogy of drama, i.e. learning to present an ethical quandary. In Heathcote's terms, in our drama experiment science students exchanged the 'mantle of the neuro-expert in neuro-enhancement' within the imagined experiential context with the 'mantle of the expert' in the representational context, having expertise in moral/ethical role-play.

Our main learning objective was to enable students to apply an academic conceptual arsenal to a concrete case of human enhancement with the help of drama. A possible weakness of our module was that the plays (perhaps due to the fact that they had to be relatively short) involved fairly stereotypical images of (the effects of) neuro-enhancers, while these effects triggered fairly polarised responses of endorsement or rejection. Although such polarised views may fail to reflect the complexities and nuances that are articulated in academic bioethical discourse, students consciously opted for polarisation because of the dramatic effect entailed in staging potentially disruptive neuro-enhancers. The enactment of a polarised debate enabled students to present a 'clear' dilemma to the audience, while keeping in mind that, by voicing extremist views, a character might lose the sympathy of the audience. In other words, although an element of exaggeration was seen as part of the dramatic situation, the students were nonetheless aware of the fact that one should not overdo this. Moreover, in the course of the process, students learned to use various aspects of language (including body language, irony, gestures and unfinished sentences) to trigger active interpretative involvement from the audience (cf. Sutton 1996). In the theatrical setting of the Science Café, this proved to be a successful approach. Drama allows for a condensed presentation of multiple perspectives on an issue (Esbjorn-Hagens and Zimmerman 2009), whilethe dilemmas and conflicts presented offered a starting point for further discussion on the assumptions underlying these various perspectives presented in the play. As we have argued, the fact that the module could be connected both with a philosophy course and with a Science Café event proved beneficial. This allowed students to connect classroom discussions with public deliberations in the 'real world', although it increased their workload. As indicated, a challenge of using drama in science education is that the design and performance of a play may prove quite time-consuming, and in this sense less time-efficient compared to more traditional ways of learning. Within an academic context of 'rational science learning' we follow the recommendation of McSharry and Jones (2000) to use scripts. It provides teachers with a sense of control and in collaboratively writing the script students engage in discussions and deepen their understanding of the issue at hand.

Due to the complex nature of teaching and learning, we are aware that many variables affect students' views on the social and scientific issues surrounding neuro-enhancement. Nonetheless, in line with experiences reported by others (referred to in this article), the results of our research underline the potential benefits of integrating science and drama. When asked whether students would recommend the course to fellow students, an overwhelming majority gave a positive answer. Science theatre clearly stimulated our students to consider the impacts of new technologies in daily life in depth and to develop arguments that would be relevant to the 'outside' world. We believe that integrating drama in 
academic science curricula will encourage and enable future scientists to assume an interactive role in the ongoing societal debate on the future impacts of techno-science.

Acknowledgments The study received funding from the European Union's Seventh Framework Programme (FP7/2007-2013), NERRI Consortium, Grant Agreement No. 321464. We are grateful to our colleagues and teachers in the course, Dr. Pieter Lemmens and Dr. Laurens Landeweerd, for their collaboration and support throughout this study.

Conflict of interest The author declares that there is no conflict of interest.

Open Access This article is distributed under the terms of the Creative Commons Attribution 4.0 International License (http://creativecommons.org/licenses/by/4.0/), which permits unrestricted use, distribution, and reproduction in any medium, provided you give appropriate credit to the original author(s) and the source, provide a link to the Creative Commons license, and indicate if changes were made.

\title{
Appendix 1: Questionnaire 1
}

\author{
Name: \\ Age: \\ Nationality: \\ Master:
}

Motivation for following this course:

Aspects of the course that attract me the most:

What do you expect to learn in this course?

Mark the box of your choice

Considering neuro-enhancement, I consider myself:

\begin{tabular}{l}
\begin{tabular}{|l|l|l|l|l|l|}
\hline A layman & & & & An expert \\
\hline
\end{tabular} \\
\begin{tabular}{|l|l|l|l|l|l|}
\hline \\
A layman
\end{tabular} \\
\hline
\end{tabular}

When I think of neuro-enhancement, I relate it to:

\begin{tabular}{|l|l|l|l|l|l|l|}
\hline \multicolumn{2}{l}{ When I think of neuro-enhancement, I relate it to: } \\
\hline Present time & & & & & & Futuristic \\
\hline Applied & & & & & & Experimental \\
\hline Fantasy & & & & & & Reality \\
\hline Positive development & & & & & & Negative development \\
\hline Theoretical & & & & & & Practical \\
\hline Interesting & & & & & & Uninteresting \\
\hline Science & & & & & & Society \\
\hline Natural & & & & & & Unnatural \\
\hline Useful & & & & & & Useless \\
\hline Frightening & & & & & & Comforting \\
\hline Lets do it! & & & & & & Don't do it! \\
\hline
\end{tabular}


What possible neuro-enhancement applications can you think of?

1)

2)

3)

4)

5)

more?

What are the potential...

...benefits

...risks?

In what domains/situations can neuro enhancement play a role?

1)

2)

3)

4)

5)

more?

Who should have a say in the debate around the development/innovative agenda of neuro enhancement? 1)

2)

3)

4)

5)

more?

Do you have experience with (performing or directing) theatrical plays?

Yes/no If so, what experience?

What do expect to learn from the assignment on the theatrical play? 


\section{Appendix 2: Questionnaire 2}

\section{Group:}

What aspects of the play did you value most? Why?

What was a less attractive aspect of the play? Why?

How can the play be improved?

To what extend could you relate to...

... the situation sketched in the play? Why/ Why not?

... the presented dilemma/challenge? Why/ Why not?

Was there one specific character that you liked the most? Why/ Why not? 


\section{Appendix 3: Questionnaire 3}

This questionnaire will not affect your grade in any possible way!

Name:

Mark the box of your choice

Considering neuro enhancement, I consider myself:

\begin{tabular}{|l|l|l|l|l|l|l|}
\hline Layman & & & & & Expert \\
\hline
\end{tabular}
\begin{tabular}{|l|l|l|l|l|l|}
\hline Layman & & & & & \\
\hline
\end{tabular}

Remember the play you created with your group

We choose this situation/scenario, because...

We choose these characters, because...

What message did you want to convey to the audience?

Mark the box of your choice

Did the following course elements help you designing the play?

\begin{tabular}{|c|c|c|c|c|c|}
\hline & $\begin{array}{c}\text { no, } \\
\text { absolutely } \\
\text { not }\end{array}$ & no & neutral & yes & yes, a lot \\
\hline Presentation of group statement (lecture 3 ) & & & & & \\
\hline Discussion sessions in lecture: & & & & & \\
\hline Sessions with your own group: & & & & & \\
\hline Information given in lectures: & & & & & \\
\hline $\begin{array}{l}\text { Examples of presented movies/theatre plays/books } \\
\text { also addressing ethical issues }\end{array}$ & & & & & \\
\hline
\end{tabular}

There were other things that helped me designing the play, namely:

The theatre assignment helped me to gain insight in:

\begin{tabular}{|c|c|c|c|c|c|}
\hline & $\begin{array}{c}\text { I strongly } \\
\text { disagree }\end{array}$ & I disagree & $\begin{array}{c}\text { I am } \\
\text { neutral }\end{array}$ & I agree & $\begin{array}{c}\text { I strongly } \\
\text { agree }\end{array}$ \\
\hline \multicolumn{6}{|c|}{$\begin{array}{l}\text { How emerging technologies could influence } \\
\text { daily life }\end{array}$} \\
\hline \multicolumn{6}{|c|}{ Future scenarios of emerging technologies } \\
\hline \multicolumn{6}{|c|}{$\begin{array}{l}\text { Personal dilemmas in daily life related to } \\
\text { neuro enhancement }\end{array}$} \\
\hline \multicolumn{6}{|l|}{ Controversies that might arise } \\
\hline \multicolumn{6}{|c|}{ Other people's opinions and arguments } \\
\hline \multicolumn{6}{|l|}{ Other people's interests } \\
\hline \multicolumn{6}{|l|}{$\begin{array}{l}\text { Complex ethical issues related to } \\
\text { neuro enhancement }\end{array}$} \\
\hline \multicolumn{6}{|c|}{$\begin{array}{l}\text { My own opinion about the dilemmas related to } \\
\text { emerging neuro technologies }\end{array}$} \\
\hline \multicolumn{6}{|l|}{ How to relate to the audience } \\
\hline Social responsibility of scientists & & & & & \\
\hline
\end{tabular}


In this theatre assignment I developed the following skills:

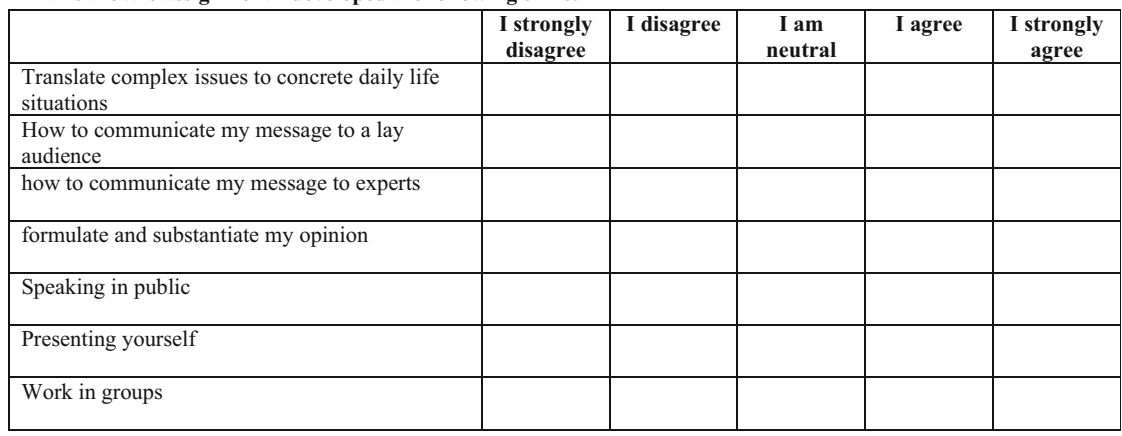

About the theatre assignment

What I valued the most about the theatre assignment was...

Because. .

What I valued the least about the theatre assignment was...

Because..

How did this assignment affect your personal opinion about neuro enhancement?

\section{About the whole course}

What I learned about philosophical and ethical debate is...

What I learned about neuro enhancement is...

Would you recommend this course to other students? And why?

\section{References}

Andersen, C. (2004). Learning in "as-if" worlds: Cognition in drama in education. Theory into Practice, 43(4), 281-286.

Aristophanes. (1971). Clouds. In M. Hadas (Ed.), The complete plays of Aristophanes (pp. 101-141). New York: Bantam.

Bacon, F. (1620/1878). Novum organum. London: Clarendon Press.

Bailey, S., \& Watson, R. (1998). Establishing basic ecological understanding in younger pupils: A pilot evaluation of a strategy based on drama/role play. International Journal of Science Education, 20(2), 139-152.

Boal, A. (1974/2008). Theatre of the oppressed. London: Pluto Press. 
Bolton, G. M. (1984). Drama as education: An argument for placing drama at the centre of the curriculum. Reading: Addison-Wesley Longman Ltd.

Bolton, G. (1985). Changes in thinking about drama in education. Theory into Practice, 24(3), 151-157.

Braund, M. (2015). Drama and learning science: An empty space? British Educational Research Journal, 41(1), 102-121.

Büchner, G. (1836/1980) Woyzeck. München: Fink.

Cakici, Y., \& Bayir, E. (2012). Developing children's views of the nature of science through role play. International Journal of Science Education, 34(7), 1075-1091.

Colucci-Gray, L., Camino, E., Barbiero, G., \& Gray, D. (2006). From scientific literacy to sustainability literacy: An ecological framework for education. Science Education, 90, 227-252.

Crease, R. (1993). The play of nature: experimentation as performance. The Indiana Series in the Philosophy of Technology. Bloomington, Indianapolis: Indiana University Press.

De Kruif, P. (1925/2002). Microbe hunters. Houghton Mifflin Harcourt.

Debré, P. (1994/1998). Louis Pasteur. [Transl. E. Forster]. Baltimore \& London: John Hopkins University Press.

Dorion, K. R. (2009). Science through drama: A multiple case exploration of the characteristics of drama activities used in secondary science lessons. International Journal of Science Education, 31(16), 2247-2270.

Eckert, M. (2012). Cinematic Spelunking Inside Plato's Cave. Glimpse Journal: The Art and Science of Seeing, 9, 42-49.

Esbjorn-Hagens, S., \& Zimmerman, M. (2009). Integral ecology: uniting multiple perspectives on the natural world. Boston, London: Integral Books.

Fels, L. (2004). Complexity, teacher education and the restless jury: Pedagogical moments of performance. Complicity: An International Journal of Complexity and Education, 1(1), 73-98.

Fels, L., \& Meyer, K. (1997). On the edge of chaos: Co-evolving worlds of drama and science. Teaching Education, 9(1), 75-81.

Gamow, G. (1966). Thirty years that shook physics. The story of quantum theory. New York: Dover.

Griffith, M. (1999). Sophocles: Antigone. Cambridge: Cambridge University Press.

Haney, C., Banks, W. C., \& Zimbardo, P. G. (1973). A study of prisoners and guards in a simulated prison. Naval Research Review, 30, 4-17.

Haraway, D. (1989). Primate visions: Gender, race and nature in the world of modern science. New York, London: Routledge.

Heathcote, D. (1978). Of these seeds becoming. In R. Shuman (Ed.), Educational drama for today's schools. Metuchen, NJ: Scarecrow.

Heathcote, D., \& Bolton, G. (1995). Drama for learning. Dorothy Heathcote's mantle of the expert approach to education. Portsmouth, NH: Heinemann.

Heathcote, D., \& Herbert, P. (1985). A drama of learning: Mantle of the expert. Theory into Practice, 24(3), $173-180$.

Hegel, G. W. F. (1821/1970). Grundlinien der Philosophie des Rechts oder Naturrecht und Staatswissenschaft im Grundrisse. Werke 7. Frankfurt am Main: Suhrkamp.

Kottler, J. A. (1994). Advanced group leadership. Pacific Grove, CA: Brooks/Cole.

Latour, B. (1984/1988). The pasteurization of France. Cambridge: Harvard University Press.

Livingston, P. (2006). Theses on cinema as philosophy. The Journal of Aesthetics and Art Criticism, 64(1), 11-18.

McNaughton, M. J. (2004). Educational drama in the teaching of education for sustainability. Environmental Education Research, 10(2), 139-155.

McSharry, G., \& Jones, S. (2000). Role-play in science teaching and learning. School Science Review, 82(298), 73-82.

Neelands, J. (1984). Making sense of drama: A guide to classroom practice. Oxford: Heinemann.

Nietzsche, F. (1872/1964). Die Geburt der Tragödie aus dem Geiste der Musik. Werke I. Frankfurt: Ullstein, pp. $21-134$.

Ødegaard, M. (2001). The drama of science education: How public understanding of biotechnology and drama as a learning activity may enhance a critical and inclusive science education. Dr. Scient. Dissertation, University of Oslo.

Ødegaard, M. (2003). Dramatic science: A critical review of drama in science education. Studies in Science Education, 39, 75.

Ødegaard, M. (2004). Gen-Gangere: A science-in-drama project about knowledge, biotechnology and Ibsen's dramatic works: Ethics in science education. School Science Review, 86(315), 87-94.

O'Neill, C. (1985). Imagined worlds in theatre and drama. Theory into Practice, 24(3), 158-165.

O’Neill, C. (1995). Drama worlds: A framework for process drama. Portsmouth, NH: Heinemann Drama. 
Pantidos, P., Spathi, K., \& Vitoratos, E. (2001). The use of drama in science education: The case of "Blegdamsvej Faust". Science \& Education, 10(1-2), 107-117.

Plato. (1935/2000). The republic. Loeb Classical Library: Plato VI. Cambridge MA: Harvard University Press.

Redington, C. (1983). Can theatre teach? An historical and evaluative analysis of theatre in education. NY: Pergamon Press.

Rothenberg, K. H., \& Bush, L. W. (2012). Manipulating fate: Medical innovations, ethical implications, theatrical illuminations. Houston Journal of Health Law and Policy, 13(1), 1-77.

Savulescu, J., ter Meulen, R., \& Kahane, G. (Eds.). (2011). Enhancing human capacities. London: Wiley.

Schaffner, M., Little, G., Felton, H. \& Parsons, B. (1984). Drama, language and learning. Reports of the drama and language research project. Speech and Drama Center, Education Department of Tasmania. NADIE papers No. 1. Tasmania: National Association for Drama in Education.

Shepherd-Barr, K. (2006). Science on stage: From doctor faustus to Copenhagen. Princeton: Princeton University Press.

Smith, C. (2015). Role-plays and drama in science learning. In R. Gunstone (Ed.), Encyclopedia in science education. Netherlands, Dordrecht: Springer.

Sutton, C. (1996). Beliefs about science and beliefs about language. International Journal of Science Education, 18, 1-18.

Verhoeff, R. P., \& Waarlo, A. J. (2013). Good intentions, stubborn practice: A critical appraisal of a public event on cancer genomics. International Journal of Science Education, Part B, 3(1), 1-24.

Watson, J. (1968/1996). The double helix: A personal account of the discovery of the structure of DNA. New York etc. NY: Simon \& Schuster.

Wieringa, N. F., Swart, J. A., Maples, T., Witmondt, L., Tobi, H., \& van der Windt, H. J. (2011). Science theatre at school: Providing a context to learn about socio-scientific issues. International Journal of Science Education, Part B, 1(1), 71-96.

Wilson, E., \& Spink, A. (2005). Making meaning in chemistry lessons. Electronic Journal of Literacy through Science. doi: 10.1126/science.13.320.268.

Yoon, H. G. (2006). The nature of science drama in science education. In The 9th international conference on public communication of science and technology (PCST-9). Seoul, Korea.

Zwart, H. (2013). Woyzeck and the birth of the human research subject: Genetic disposition and the naturenurture debate through the looking-glass of fiction. Bioethica Forum, 6(3), 97-104.

Zwart, H. (2014a). What is nature? On the use of poetry in philosophy courses for science students. Teaching Philosophy, 37(3), 379-398.

Zwart, H. (2014b). Limitless as a neuro-pharmaceutical experiment and as a Daseinsanalyse: On the use of fiction in preparatory debates on cognitive enhancement. Medicine, Health Care \& Philosophy: A European Journal, 17(1), 29-38. 